\title{
$5083 \mathrm{Al}$ 合金の冷間圧延と表面残留応力
}

\author{
中山栄浩* 鷹 合徹也* 木 村 真 一**
}

J. Japan Inst. Metals, Vol. 55, No. 12 (1991), pp. 1307-1314

Surface Residual Stresses in Cold Rolled 5083 Aluminum Alloy

Yoshihiro Nakayama*, Tetsuya Takaai* and Shinichi Kimura**

The generation behavior and macroscopic and microscopic residual stresses, generated and retained in 5083 aluminum alloy plate during the course of cold rolling, were studied mainly by X-ray diffraction procedures. The results obtained were as follows:

(1) X-ray elastic constants measured for the (222) crystal plane were invariable and no effect of the reduction of area on the value was observed. The measured values of the X-ray elastic constants were almost equivalent with those measured mechanically by applying a strain gauge.

(2) According to the estimations by integrated intensity of the diffraction profile at the specimen surface, no clear effect of the reduction of area on the texture was observed.

(3) The macroscopic residual stresses measured for the cold rolled specimen surface along the rolling direction showed both tensile and compressive characteristics and decreased with increasing reduction of area.

(Received April 3, 1991)

Keywords: macroscopic residual stress, microscopic residual stress, cold rolling, X-ray elastic constant, texture, integrated intensity

I. 緒言

前報(1)では圧延加工により生じる巨視的および微視的な 残留応力が，衝撃破壊の際に吸収されるエネルギーに执よ ぼす影響について報告したが，試料に残留応力が導入され る際の圧延加工条件と, 発生する巨視的な残留応力との関 係には不明な点が多く, 残留応力の発生因子が多岐にわた ることが推測された. 各種塑性加工により生じる残留応力 に関する研究は大変多いが, 圧延加工に関寸る研究 ${ }^{(2)}$ は比 較的少なく、アルミニウムを研究対象として選んだものは ほとんどみられない。

近年, 応力測定に X 線回折を利用した方法が広く用い られているが，機械的に求めた応力值と $\mathrm{X}$ 線を利用して 求めた值の不一致, 拉よび高度の加工により発達した集合 組織の影響など，実際に応力測定を行う上でいくつかの問 題点がある.

本報では，供試材としてアルミニウム合金を選び，X 線回折により応力を求める際の問題点, および圧延試料の 形状が異なる場合, すなわち圧延加工時の幾何学的拘束状 態が残留応力の発生に括よぼす影響に関して, 巨視的およ び微視的残留応力の観点から実験的に検討を加えた.
II. 実 験 方 法

\section{1. 試 料}

実験試料は Table 1 に示す化学成分および機械的性質 をもつ $5083 \mathrm{Al}$ 合金展伸材で，幅 $15 \mathrm{~mm}$ ，長さ $200 \mathrm{~mm}$ 拈よび厚さ $5,10,15 \mathrm{~mm}$ である 3 形状の試料を圧延試料 とした．な初試料長手方向が板材の圧延方向と平行になる よう切り出した. 試料に残存する応力を除去するため, 温 度 $623 \mathrm{~K}$ で $18 \mathrm{ks}$ の焼なまし処理を施した。圧延加工は 4 段ロール圧延機(容量 $98 \mathrm{kN}$, ワークロール直径 106 $\mathrm{mm}$, 圧延速度 $0.8 \mathrm{~m} / \mathrm{s}$ )を用い, 油潤滑の条件で同一方向

Table 1 Chemical composition (mass\%) and mechanical properties of the specimen.

\begin{tabular}{c|c|c|c|c|c|c|c|c|c}
\hline \hline $\mathrm{Si}$ & $\mathrm{Fe}$ & $\mathrm{Cu}$ & $\mathrm{Mn}$ & $\mathrm{Mg}$ & $\mathrm{Cr}$ & $\mathrm{Zn}$ & $\mathrm{Ti}$ & $\mathrm{V}$ & $\mathrm{Al}$ \\
\hline 0.143 & 0.184 & 0.020 & 0.625 & 4.648 & 0.084 & 0.008 & 0.014 & 0.0083 & $\mathrm{bal}$. \\
\hline \hline & Tensile strength & & $321 \mathrm{MPa}$ \\
\hline \multicolumn{3}{c|}{ Yeild strength } & \multicolumn{3}{|c}{$170 \mathrm{MPa}$} \\
\hline \multicolumn{3}{c}{ Elongation } & \multicolumn{3}{c}{$21 \%$} \\
\hline
\end{tabular}

* 山梨大学工学部機械システム工学科 (Faculty of Engineering, Yamanashi University, Koufu, Yamanashi)

** 山梨大学学生 (Undergraduate Student, Yamanashi University, Koufu, Yamanashi) 
Table 2 Reduction of area of the specimen.

\begin{tabular}{c|c|c|c|c|c|c|c}
\hline \hline Initial thickness & \multicolumn{7}{|c}{ Total reduction of area (\%) } \\
\hline $5 \mathrm{~mm}$ & & 20 & & 40 & 60 & 80 & \\
\hline $10 \mathrm{~mm}$ & 10 & 20 & 30 & 40 & 60 & 80 & 85 \\
\hline $15 \mathrm{~mm}$ & 10 & 20 & 30 & 40 & 60 & & \\
\hline
\end{tabular}

に圧延を行った．な持圧延は室温で行い， 1 パス当りの圧 下量は $0.3 \mathrm{~mm}$ 一定とした. 以上の条件で圧延加工を繰返 し行い，3 形状の試料について最終的に Table 2 に示す各 圧延率を得た。

\section{2. 実験方法}

圧延加工により発生した巨視的および微視的な残留応力 は X 線回折現象を利用して非破壊的に求めた。各々の測 定条件は Table 3 に示す通りである。また圧延試料の厚 さ方向の硬さの変化は, 微小ビッカース硬度計を用いて測 定した.

\section{（1） $X$ 線的弾性定数の測定}

$\mathrm{X}$ 線回折による残留応力の測定は，X 線の入射方向に 対して特定の幾何学的位置にある結晶粒による回折線を利 用して測定が行われるため，機械的に求めた残留応力と異 なる場合がある(3)-(5)。これは主に測定回折面の弾性定数 が，機械的に求めたものと異なることに起因する現象であ ると考えられている(6). したがってX 線回折によって残 留応力を求める場合, 測定回折面の弾性定数を予め求めて 扣く必要がある。

本研究では，従来から利用されている曲げ荷重負荷用治 具(7)を用い，試験片裏面に取り付けたひずみゲージにより 応力の校正を行いながら試験片に任意の弾性曲げ応力を負 荷した。この状態で X 線回折像から測定回折面のひずみ を求め, $\mathrm{X}$ 線的弾性定数 $S_{1}$ 扣よび $S_{2} / 2$ より測定回折面 (hkl)の弾性定数 $E_{(\mathrm{hkl})}$ を決定した.

また残留応力の測定に扣よぼす X 線侵入深さの影響に ついて検討を加えるため, 波長の異なる $\mathrm{CuK \alpha}, \mathrm{Cr} K \alpha$ 特 性 X 線を用いて X 線的弾性定数の測定を行った。

\section{(2) 巨視的残留応力の測定}

従来, $\mathrm{X}$ 線侵入深さの範囲内では 2 次元応力状態が仮 定され残留応力の測定が行われてきた。しかし，X線侵 入深さの範囲内で試料面法線方向の応力に急激な勾配がみ られる場合, 2 次元状態を想定して残留応力の測定を行 と大きな誤差を生じることがある(8).

本研究ではこの影響を考慮して, Noyan ${ }^{(8)}$ 特よび Dölle ら (9)による方法により 3 次元的に残留応力の評価を行 った. 残留応力の測定は Fig. 1 に示す座標系について $\sin ^{2} \Psi$ 法で行った。ここでは $\Phi$ 角を $0^{\circ}, 45^{\circ}, 90^{\circ}$ に選び， $\Psi$ 角 $0^{\circ} \sim \pm 45^{\circ}$ の範囲で $(222)$ 面について回折角 $2 \theta$ の測 定を行った. Fig. 1 の座標系に拈いて，任意の X 線入射 角 $\Phi, \Psi$ に拈けるひずみ $\varepsilon(\Phi, \Psi)$ は次式で与えられるもの とした(8)(9)

$$
\begin{aligned}
\varepsilon(\Phi, \Psi)= & \left(S_{2} / 2\right)\left\{\sigma_{11} \cos ^{2} \Phi+\sigma_{12} \sin 2 \Phi\right. \\
& \left.+\sigma_{22} \sin ^{2} \Phi-\sigma_{33}\right\} \sin ^{2} \Psi \\
& +\left(S_{2} / 2\right) \sigma_{33}+S_{1}\left(\sigma_{11}+\sigma_{22}\right. \\
& \left.+\sigma_{33}\right)+\left(S_{2} / 2\right)\left\{\sigma_{13} \cos \Phi\right. \\
& \left.+\sigma_{23} \sin \Phi\right\} \sin 2 \Psi
\end{aligned}
$$

ここで, 応力 $\sigma$ は Fig. 1 中の L 座標系に関する応力成分 を表し， $\sigma_{11}$ は圧延方向に垂直な幅方向， $\sigma_{22}$ は圧延方向 扣よび $\sigma_{33}$ は試料面法線方向の残留応力, $\sigma_{12}, \sigma_{13}, \sigma_{23}$ は 各々添完で示す断面に作用しているせん断残留応力成分

\begin{tabular}{|c|c|c|c|}
\hline & $\begin{array}{c}\text { X-ray elastic } \\
\text { constant measurement }\end{array}$ & $\begin{array}{l}\text { Macroscopic residual } \\
\text { stress measurement }\end{array}$ & $\begin{array}{l}\text { Microscopic residual } \\
\text { stress measurement }\end{array}$ \\
\hline Characteristic X-ray & $\begin{array}{l}\mathrm{Cu} K \alpha(40 \mathrm{kV}, 30 \mathrm{~mA}) \\
\mathrm{Cr} K \alpha(30 \mathrm{kV}, 10 \mathrm{~mA})\end{array}$ & $\mathrm{Cr} K \alpha(30 \mathrm{kV}, 10 \mathrm{~mA})$ & $\mathrm{Cu} K \alpha(40 \mathrm{kV}, 30 \mathrm{~mA})$ \\
\hline Irradiated area & - & $5 \mathrm{~mm} \times 1 \mathrm{~mm}$ & - \\
\hline $\begin{array}{l}\text { Divergence slit } \\
\text { Scatter slit } \\
\text { Receiving slit }\end{array}$ & $\begin{array}{l}1^{\circ} \\
0.15^{\circ} \\
1^{\circ}\end{array}$ & - & $\begin{array}{c}1^{\circ} \\
0.15^{\circ} \\
1^{\circ}\end{array}$ \\
\hline Detector & \multicolumn{3}{|c|}{ Scintillation counter } \\
\hline Scanning mode & Step & Continuous & Step \\
\hline Filter & Nickel, Vanadium & Vanadium & Nickel \\
\hline
\end{tabular}

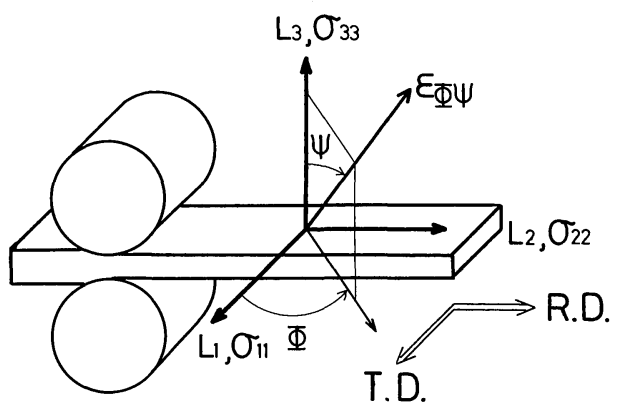

Fig. 1 Schematic illustration of relation between rolling direction and stress axes.

Table 3 X-ray conditions. 
である。また，X線的弾性定数は $S_{1}=-(v / E),\left(S_{2} / 2\right)$ $=(1+v) / E$ で定義される。な拈， $\sigma_{33}$ はX線侵入深さ内 の平均的な值で与えられ, 試料表面では当然 0 であるが, 本実験の上らな圧延加工による場合，X線侵入深さの範 囲内で大きく変化することが考兄られる，このような場合， $\mathrm{X}$ 線侵入梁さの範囲内で $\sigma_{33}=0$ を仮定し， 2 次元状態で 残留応力の計算を行うと, 式 (1)の関係から $\sigma_{11}, \sigma_{22}$ など の応力成分に誤差を生じることになる.

式( 1 ) より $\pm \Psi$ 角に対して, $a 1=\left\{\varepsilon\left(\Phi, \Psi^{+}\right)+\varepsilon\left(\Phi, \Psi^{-}\right)\right\}$ $/ 2, a 2=\left\{\varepsilon\left(\Phi, \Psi^{+}\right)-\varepsilon\left(\Phi, \Psi^{-}\right)\right\} / 2$ をとると, 式 $(2)$ 抌上 び ( 3 )が得られる.

$$
\begin{aligned}
a 1= & \left(S_{2} / 2\right)\left\{\sigma_{11} \cos ^{2} \Phi+\sigma_{12} \sin 2 \Phi+\sigma_{22} \sin ^{2} \Phi\right. \\
& \left.-\sigma_{33}\right\} \sin ^{2} \Psi+\left(S_{2} / 2\right) \sigma_{33} \\
& +S_{1}\left(\sigma_{11}+\sigma_{22}+\sigma_{33}\right)
\end{aligned}
$$

$a 2=\left(S_{2} / 2\right)\left\{\sigma_{13} \cos \Phi+\sigma_{23} \sin \Phi\right\} \sin |2 \Psi|$

$\Phi=0^{\circ}, 90^{\circ}$ 亿扒ける $a 1-\sin ^{2} \Psi$ 線図の傾きおよび切片か ら $\sigma_{11}, \sigma_{22}, \sigma_{33}$ を， $\Phi=45^{\circ}$ での傾きから $\sigma_{12}$ を求め, 同様 飞 $\Phi=0^{\circ}, 90^{\circ}$ での $a 2-\sin |2 \Psi|$ 線図の傾きから $\sigma_{13}, \sigma_{23}$ を 算出した.

\section{(3) 微視的残留応力の測定}

微視的なひずみは, Hall の方法 ${ }^{(10)}$ により式(4)にした がって求めた。本実験の場合，(200)拈よび(400)面を測 定回折面として選び, 回折線の幅広がりの程度から微視的 なひず反を求めるものである.

$$
\beta \cos \theta / \lambda=2 \eta \sin \theta / \lambda+1 / \varepsilon
$$

ここで, $\beta$ は回折線の幅広がり, $\theta$ は回折線のブラッグ角, $\lambda$ は測定 $\mathrm{X}$ 線波長, $\eta$ は微視的ひずみ(不均一ひずみ)括よ び $\varepsilon$ は結晶子の大きさである.

有間ら ${ }^{(11)}$ 执よびカリティ(12)によれば，式(4)のひずみ $\eta$ は式 $(5)$ ) 応力 $\sigma$ に書き換光られる.

$$
\beta \cos \theta / \lambda=2\left(\sigma / E_{(\mathrm{hkl})}\right) \sin \theta / \lambda+1 / \varepsilon
$$

ここで， $\sigma$ は式(4)の微視的なひずみに対応する応力, $E_{\text {(hkl) }}$ は測定回折面の弾性定数である. 式 (4)のひずみ $\eta$ は引張り拉よび圧縮の両変形を含んで括り, この両者が等 しいと仮定すると, 最大引張りあるいは圧縮応力 $\sigma$ は式 ( 5 )から与えられる ${ }^{(12)}$.

\section{III. 実験結果および考察}

\section{1. $\mathbf{X}$ 線的弾性定数}

$\mathrm{X}$ 線により残留応力を求める場合, 弾性定数の回折面 依存性が問題(9)(13)(14) となる. 本研究では各圧延率の試料 から板状の引張り試験片を切り出し，ひずみゲージを用い て機械的に弾性定数を求めるとともに, 弾性曲げ応力を負 荷した状態で，X線を用いて回折面間隔の変化すなわち 格子ひずみの測定を行い，X 線的弾性定数を求めた．X 線を利用して弾性定数を求める際, 試料中に残留応力が残 存していると，応力を機械的に負荷したとき，実際に試料 の回折に寄与する結晶の変形に対して残留応力の影響が考
えられる、本研究ではこの影響を低減するため，圧延によ る加工組織の大部分を残した状態で残留応力のみを取り除 くことを目的とし，先に報告したように残留応力がほぼ除 去され, 加熱温度が最も低い条件(温度 $473 \mathrm{~K}$ 保持時間 $100 \mathrm{~min})^{(1)}$ を選び，残留応力を低減するための焼なまし 処理を施した.

Fig. 2(a)，(b)はX 線的に弾性定数を計測した結果の一 例を示したものである. Fig. 2(a) と示すように，Cr 管球 を用い(222)面のひずみを測定した場合， $\mathrm{M}-\sigma 1$ 線図 $(\mathrm{M}$ ： $\varepsilon-\sin ^{2} \Psi$ 線図の勾配, $\sigma 1$ : 負荷応力) 飞子示すように $\varepsilon-\sin ^{2} \Psi$ 線図の勾配 M は弾性負荷応力の増加と対応して 増加している. また測定点の直線性も比較的良好である. 一方 Fig. 2(b)に示したように, CuK $\alpha$ 線により (400)面に ついて求めた結果は, (222) 面の結果とは対照的に, $\sin ^{2} \Psi$ に対する格子面ひずみ $\varepsilon$ に規則性がみられず，弾性 定数を求める際の $\mathrm{M}-\sigma 1$ 線図扣よび $\varepsilon_{\phi=0^{\circ}}-\sigma 1$ 線図にはよ い直線関係は得られない。(222) 面による回折角 $2 \theta$ は約 $154^{\circ}$ と高角側に位置するのに対し，(400) 面では約 $98^{\circ}$ と 低角であること，拈よび X 線侵入深さが $\mathrm{Cr} K \alpha$ と $\mathrm{Cu} K \alpha$ 線で異なり， $\Psi$ 角 $\left(0^{\circ} \sim 45^{\circ}\right)$ による変化も $\mathrm{Cr} K \alpha$ 線では 18 $27 \mu \mathrm{m}$ と小さいが, $\mathrm{CuK} \alpha$ 線の場合 $25 \sim 66 \mu \mathrm{m}$ と比 較的大きいことなどが原因の一部と考兄られる.本実験の ごとく弾性曲げ応力を負荷した試料については, 負荷応力 は中立軸に対称に圧縮から引張応力へと深さ方向に直線的 に変化する．X線の侵入深さの範囲内でこのような応力 勾配が存在するので, 波長の短い $\mathrm{Cu} K \alpha$ 線を用いた場合， $\mathrm{X}$ 線侵入深さが大きい分だけ相対的に深い位置からの回 折像が得られその影響が表れたためとる考兄られる。その ため当然のことながら応力勾配の影響 ${ }^{15)}$ が $\mathrm{Cr} K \alpha$ 線より 大きく, CuK $\alpha$ 線による格子面ひずみの測定值によい直線 関係が得られなかったのであろら。

各圧延率の試料について求めた $\mathrm{X}$ 線的弾性定数, 拉よ び機械的に求めた弾性定数を Fig. 3 亿比較して示した. 横軸は方位関数 $3 \Gamma$ であり，機械的に多結晶体の弾性定数 を求めた場合の方位関数は, 全方位に関して平均操作を行 うことにより $3 \Gamma=0.6$ となる(13). な敃図には弾性定数の 上限と下限を与える Voigt 抢よび Reuss モデルによる計 算結果も合わせて示した。 米谷ら (2)(16) は圧延加工を施す ことにより機械的な弾性定数は变化すると報告しており, 平ら (17) も塑性変形を加えた場合, $\mathrm{X}$ 線的弾性定数は大き く変化することを報告している．しかし本実験結果にはそ の上らな傾向はみられず, $\mathrm{Cr} K \alpha$ 線により求めた (222)面 に関するX線的弾性定数および機械的に測定した結果は 相互に比較的よい一致を示し, 圧延加工度の影響も圧延率 10〜85\%の範囲内ではほとんど認められなかった。

以上の結果を参照し，以下に求めた残留応力はすべて $\mathrm{Cr} K \alpha$ 線を用い(222)面について測定を行った. 

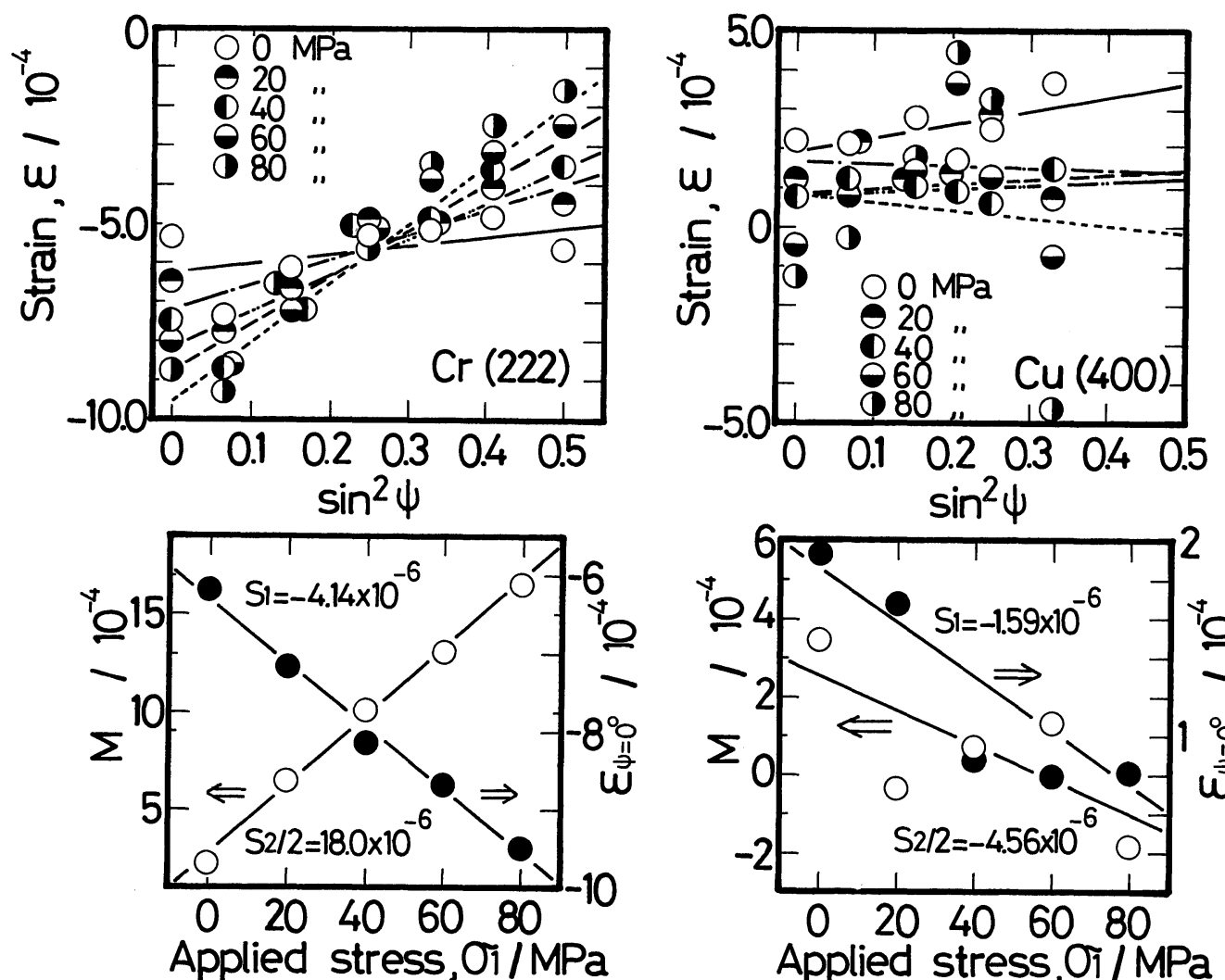

(a)

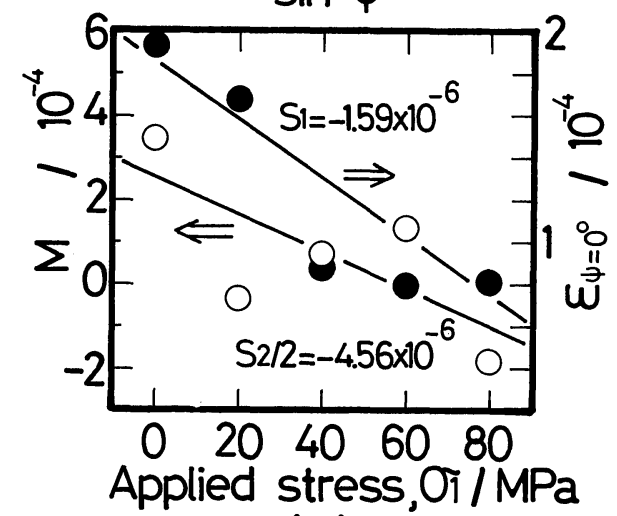

(b)

Fig. $2 \varepsilon$ - $\sin ^{2} \Psi$, M-applied stress and $\varepsilon_{\psi=0^{\circ}}$-applied stress diagrams at various applied stress. (a) $\mathrm{Cr} K \alpha_{1}$, (b) $\mathrm{CuK} \alpha_{1}$, specimen : $30 \%$ cold rolled.

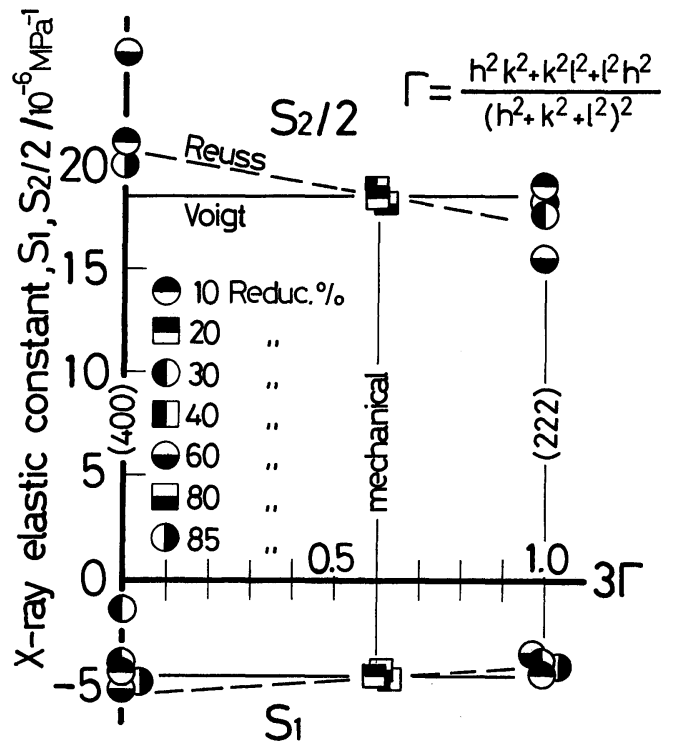

Fig. 3 X-ray elastic constants for $5083 \mathrm{Al}$ alloy vs. $3 \Gamma$.

\section{2. 残留応力の測定と加工組織}

圧延加工を施すことにより圧延集合組織が形成され, $\mathrm{X}$ 線的に応力を測定する際々の影響(9)が懸念される. 各 種塑性加工を加え集合組織を有するものの残留応力を測定 する場合, Dölle ${ }^{(9)}$ は(hhh) 执よび(h00)面の測定を推奨し ている。これは集合組織を有する試料に抏いても，X 線 入射角 $\Phi, \Psi$ の変化によらずこれらの面に関するX 線的弾 性定数は一定となることによる. 本研究では, (222)面を 測定回折面としているが，各圧延率で集合組織が変化する ことが考えられるので, この点についてあらかじめ検討を 加壳た。

Fig. 4 は圧延組織の発達度を簡便的に評価する(18)ため, (222)面に関して各 $\mathrm{X}$ 線入射角に颃いて得られる積分強度 を示したものである.な推積度 $\xi(\Phi, \Psi)$ は吸収補正を行 ったのち平均積分強度で除した值であり, この值がすべて の $\Phi, \Psi$ 角についてほぼ 1 であるとき結晶はランダムに分 布，すなわち等方であると言える(18).

圧延方向 $\left(\boldsymbol{\Phi}=90^{\circ}\right)$ には $\boldsymbol{\Psi}= \pm 20^{\circ} \sim 30^{\circ}$ 付近の集積度に ピークがみられ, 他の部分では集積度は低い、今後極図形 


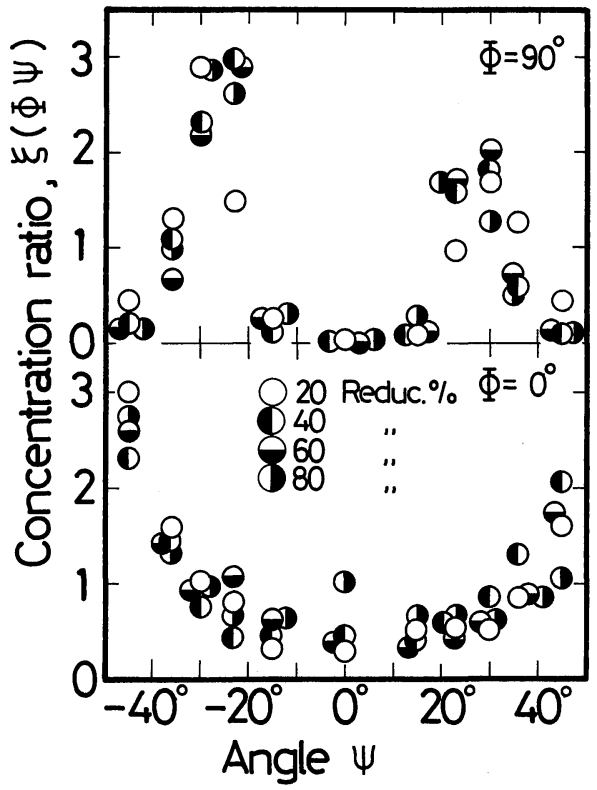

Fig. 4 Variation of relative intensity of diffraction due to cold rolling. $\left(\Phi=90^{\circ}\right.$ : Rolling direction, $\Phi=0^{\circ}$ : transverse direction)

などを用いさらに詳細に検討を加えることが望まれるが， (222) 面と幾何学的に $20^{\circ} \sim 30^{\circ}$ の角度をなす面として (112)，(123)，(113)执よび(133)面などがある．本実験で 用いた $\mathrm{Al}$ 合金の圧延集合組織は，圧延面と平行に(110) 扣よび(112)面が発達する(14)(19) ことから，20〜30 のピ 一クは(112)面に相当するものと思われる. 一方， $\Phi=0^{\circ}$
方向にも $\Psi$ 角の変化による集積度に変化がみられるが, 本実験の測定範囲ではいずれの面に対応するものであるか を特定することは困難である.

試料内部では当然のことながら集合組織が発達, 変化す ることが考えられるが，上述の X 線回折により得られた 結果によると, 試料表面 (X 線侵入深さの範囲内)に関し ては, 圧延加工度の増加に伴う組織変化はほとんどみられ ない，したがって，X線回折像から残留応力を評価する 上で，圧延率の相違にかかわらず残留応力はほぼ同等な状 態で測定，評価し得るものと想定した。

\section{3. 圧延面の巨視的な残留応力}

厚さの異なるそれぞれの試料に発生した圧延表面の巨視 的な残留応力を Fig. 5(a)〜 (c) に示す.この結果による と, 例えば厚さ $5 \mathrm{~mm}$ の試料に生じた圧延方向(以後 R.D. 方向と記載) の残留応力 $\sigma_{22}$ は， $20 \%$ の圧延加工で圧 縮応力を示し, 圧延率の増加に対応して引張応力へと変化 する．さらに $80 \%$ をて圧延することにより減少する変化 を示した. また圧延方向に垂直な幅方向 (以後 T.D. 方向 と記載)の応力 $\sigma_{11}$ は, R.D. 方向の応力と同様な変化を示 すが，いずれも圧縮残留応力であった.

一方厚さ 10 およ゙ $15 \mathrm{~mm}$ 試料の残留応力は $5 \mathrm{~mm}$ の ものと異なる傾向を示した．R.D. 方向では圧延率にかか わらず引張応力を示し，圧延率の小さい試料でその值は大 きく，最大で降伏応力の約 $75 \%$ の值を示したが，圧延率 $30 \%$ で極小值を取り，圧延率の増加とともに減少する変 化を示した．さらに圧延加工度が高い $80 \%$ 試料の残留応 力はほぼゼロであった。

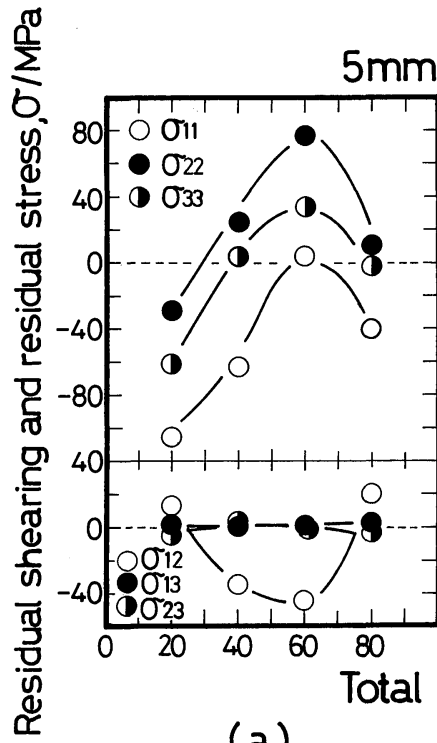

(a)
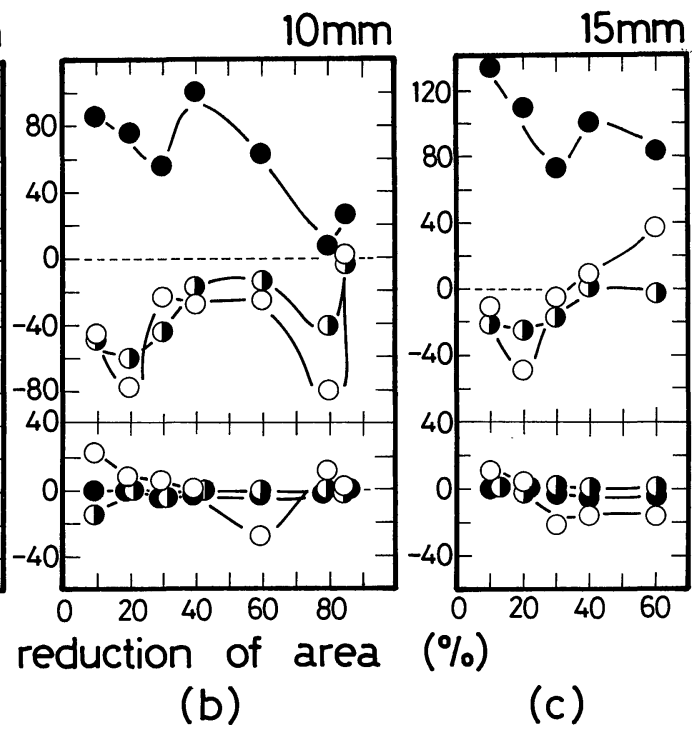

(c)

Fig. 5 Macroscopic residual stresses at the rolling surface. Thickness (a) $5 \mathrm{~mm}$, (b) $10 \mathrm{~mm}$ and (c) $15 \mathrm{~mm}$. 
また, 試料表面に垂直な方向の残留応力成分 $\sigma_{33}$ は, い ずれの厚さの試料も T.D. 方向の応力 $\sigma_{11}$ と類似の変化を 示すことから，両者に何等かの対応関係が有るものと思わ れるが，今後の検討課題と考えている.な特参考までに， $\sigma_{33}=0$, すなわち 2 次元状態を仮定して, 残留応力 $\sigma_{11}, \sigma_{22}$ などについて計算を行った結果によると, この場合，最大 で70\%程度応力を大きく評価する場合があった.

次にせん断残留応力に関して若干の検討を加える. いわ ゆる有向性加工層 ${ }^{(20)(21)}$ を生じるよらな加工を行った場 合, 加工方向 (本実験に拈ける R.D. 方向)に平行な方向の $2 \theta-\sin ^{2} \Psi$ 線図には， $\pm \Psi$ 角に対して回折角がわん曲する いわゆる“ $\Psi$-Splitting”を生じることが報告されてい る(22). これはX 線侵入深さ内に存在する残留せん断応 力に起因する現象である(20)-(22). Fig. 6(a), (b)に2 2 $\sin ^{2} \Psi$ 線図の一例を示すが，圧延加工試料により特徵的な 変化を示している. 先ずT.D. 方向については, 測定結果 に若干のバラッキはあるものの“ “S-Splitting”と思われる よらな測定点の変化はみられない. しかし, Fig. 6(b)に みられるよらに測定点にらねり ${ }^{(23)}$ が認められる(この T.D. 方向の測定点のらねりは他の圧延試料にも同様にみ られ, 圧延加工度の増加と対応してらねりも増加するが, 特に厚さ $5 \mathrm{~mm}$ の試料で顕著にあらわれた). 一方，有向 性加工方向すなわち R.D. 方向には，Fig. 6(a)に示したよ らに，明瞭な“ $\Psi$-Splitting”を生じている.このことと対 応して, Fig. 5 に示したせん断残留応力 $\sigma_{23}$ (これがこの場 合の $\Psi$-Splitting を生じる要因) に変化がみられる. 他方,

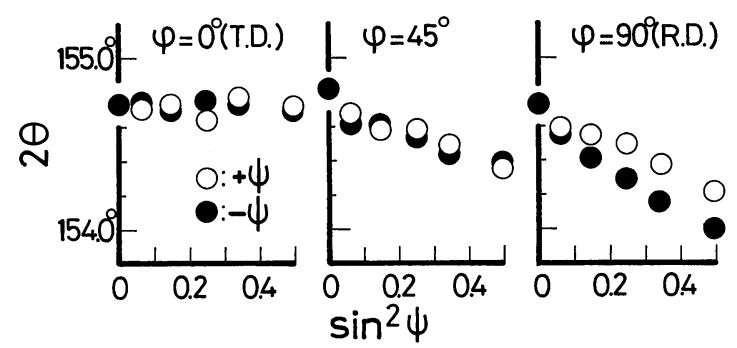

(a)

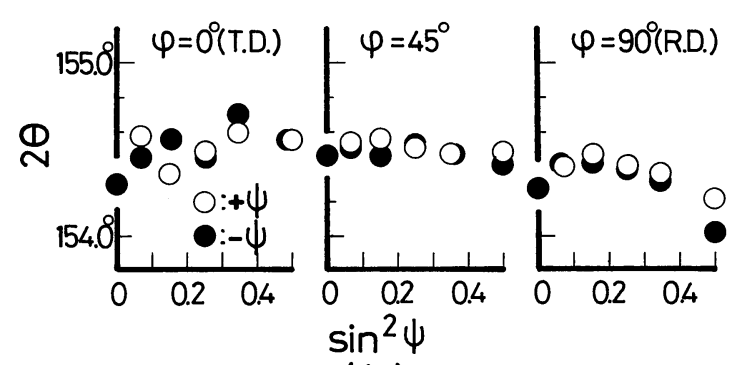

(b)

Fig. 6 Relations between diffraction angle $2 \theta$ and $\sin ^{2} \Psi$

(a) $10 \%$ reductions of area for the $10 \mathrm{~mm}$ specimen.

(b) $20 \%$ reductions of area for the $5 \mathrm{~mm}$ specimen.
Fig. 6(b)に示した結果ではそのよらな傾向を顕著に示さ ないが，士角について測定点がいずれも放物線状に変 化している．測定方向の残留応力が X 線の侵入深さ方向 に関して, 直線的に変化するよらな応力分布を示すモデル に関する $2 \theta-\sin ^{2} \Psi$ 線図上では, 測定点が放物線状に変化 することが知られている(13).この場合このような応力分 布を生じているものと思われる.

\section{4. 巨視的な残留応力発生と圧延条件}

Fig. 5 に示したよらに，試料厚さ特よび圧延加工度など 加工条件が異なると発生する残留応力は著しく異なる．圧 延加工による残留応力の発生原因として，(1)加工に伴ら試 料断面内での不均一な塑性変形, (2)加工とともに発達する 集合組織の影響の 2 づ考えられるが，本研究では，主 に不均一な塑性変形により残留応力が生じるものと考光, 以下の検討を進めることにする.

圧延加工時の幾何学的な拘束状態, すなわち試料と口ー ルの相対的な寸法の関係が残留応力の発生に影響をおよぼ すと考光，従来から行われているロール間げき比(投影接 触長さ/平均板厚, $l / H m)^{(24)(25)}$ と巨視的残留応力の関係 を求めたところ Fig. 7 に示す関係が得られた. T.D. 万向 の残留応力 $\sigma_{11}$ はいずれの場合も圧縮応力を示すものの, ロール間げき比との間には相関関係はみられない。しかし R.D. 方向の残留応力 $\sigma_{22}$ は $l / H m$ の值が小さい(ロール-試 料間の接触長さに対して板厚が厚い)場合引張応力を示し, $l / H m$ 值の増加と対応して減少する傾向をみせた。

圧延条件により最大圧力の位置および表面部と中心部で

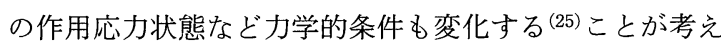
られるが, 圧延加工の際, 試料はその断面を減少しながら ロールから圧力とともに大きな摩擦力を受けている．この 摩擦力のため表面の変形が内部の変形より相対的に抑制さ れることが考えられる(25).この効果は同時に試料厚さが

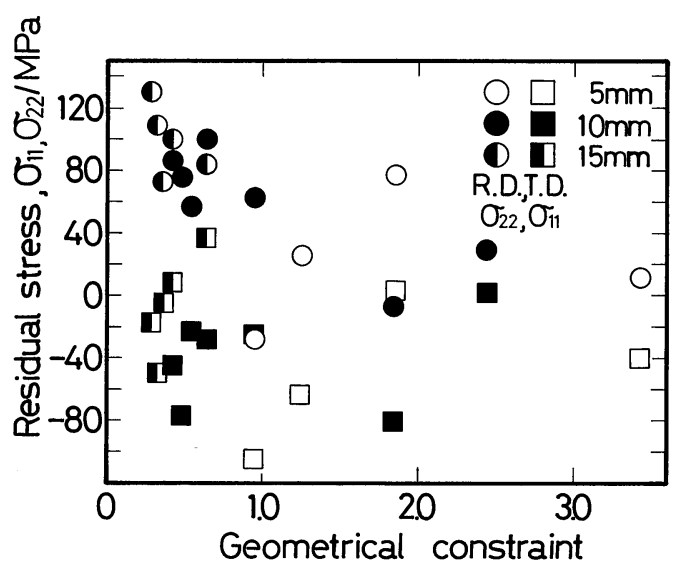

Fig. 7 Relations between macroscopic residual stress and geometrical constraint. (geometrical constraint: ratio of contact length to mean thickness) 


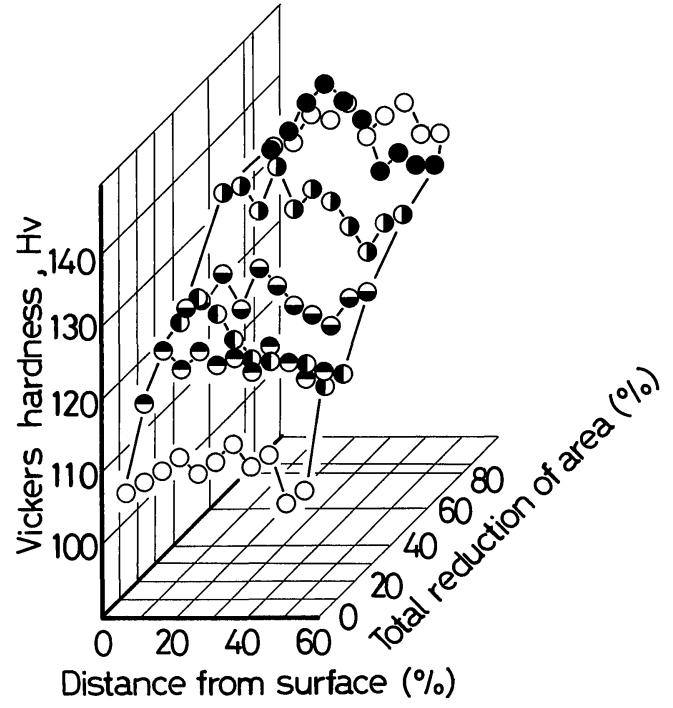

Fig. 8 Vickers hardness distributions at various reduction area for the $10 \mathrm{~mm}$ specimen.

厚いほど，すなわち $l / H m$ が小さいほどその影響が大きい ものと思われ，その結果試料表面よりやや内部の塑性的な 変形(伸長)が相対的に大きくなる傾向を生じるものと考兄 られる.このことが先に Fig. 5 に示したように試料表面 に比較的大きな引張残留応力を発生する原因と思われる.

試料断面内の硬さ分布から，塑性変形の不均一さを評価 するにはさらに検討を要すると思われるが, 参考までに,

厚さ $10 \mathrm{~mm}$ 試料の硬さ分布を測定した結果を Fig. 8 亿示 した(Fig. 8 は断面内(厚さ方向)の硬さ分布を圧延表面か らの距離並びに減面率との関係で示したものである).

\section{5. 圧延面の微視的な残留応力}

ここでの微視的応力とは, 炭素鋼などの 2 相合金にみ られる相応力ではなく, 結晶粒オーダーの格子ひずみある いは転位, 析出物など微小な応力場, および格子欠陷近傍 等の不均一なひずみ分布に基づく微視的応力である。この 微視的なひずみは X 線回折ピークの幅広がりの度合いか ら評価されるが，圧延加工のよらな大きな塑性変形による 場合, 結晶粒微細化および格子の不均一ひずみの影響が重 なり合ってピーク幅広がりとして測定される傾向がある. 本研究では上記の 2 つ因子を分離するため, Hall の方 法(10)を用い結晶格子の不均一ひずみすなわち微視的な残 留応力を求めることを試みた. Fig.9 は式（4)にしたが ってHall の方法により不均一ひずみを，拈よび Fig. 3 Voigt のモデルょり算出した $(200)$ 面の弾性定数 $\left(E_{(200)}\right.$ $=70.4 \mathrm{GPa})$ を用い, 式 $(5)$ により微視的な残留応力 ${ }^{(12)}$ を計算した結果の一例(厚さ $10 \mathrm{~mm}$ の試料)を示したもの である。

図に示したように，10６0\%の圧延加工を施した場合，

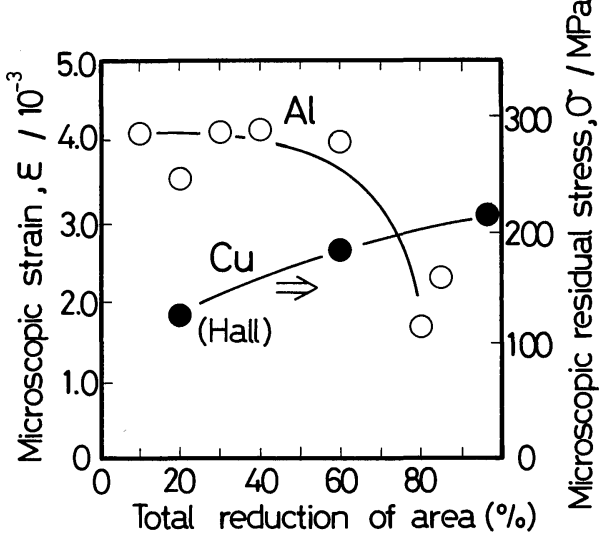

Fig. 9 Microscopic residual stresses at the rolling surface for the $10 \mathrm{~mm}$ specimen.

試料表面の微視的な残留応力は通常の引張試験で得られる 引張強さ $(321 \mathrm{MPa})$ に相当する大きな值を示すが，その 後 $80 \%$ 相当の強加工を行うことにより，急激に減少する ことは前述の巨視的な残留応力の場合と同様な傾向であ る. 小林ら ${ }^{(26)} は$ 強加工を行らことによる加工熱のため動 的な回復が起こり，その結果残留応力(巨視的な応力では あるが)が減少することを報告しているが，本研究の加工 範囲内では Fig. 4 亿示した圧延組織発達の変化, および Fig. 8 亿示した硬さの測定結果からも動的な回復を示唆す る現象はみられないまをた，Hall(10)は供試材として銅を 選び同様な検討を行って拉り，その結果を同じくFig. 9 に示したが，99\%の強加工を施した試料についても微視 的な応力は増加するとしている。本実験で $\mathrm{Al}$ 合金につい て得た結果は Hall の結果とは対照的であり，高圧延加工 に基づく微視的残留応力は材料の違いおよび加工状態など により複雑な変化を示するのと思われるが，いずれにして も本実験の場合, 圧延加工により発生した微視的残留応力 は予想以上に大きい值を示した.

\section{N. 結言}

異なる厚さを有する $5083 \mathrm{Al}$ 合金に冷間圧延加工を施 し，発生する巨視的招よび微視的な残留応力について検討 を加えた。また残留応力測定時の問題点について合わせて 実験的に検討を行った結果, 以下に示す結論を得た。

（1） $5083 \mathrm{Al}$ 合金の (222) 面に関する X 線的弾性定数を 測定したが，X 線的弾性定数は圧延加工度によらず一定 值を示し, 機械的に求めた弾性定数とよく一致した.

（2）回折線積分強度を用い，圧延表面の集合組織を簡便 的に評価した結果, 本実験の範囲内では圧延加工度に対す る変化はほとんどみられなかった。

（3）試料表面に発生した圧延方向の巨視的な残留応力 は, 加工時の幾何学的拘束状態をあらわすロール間げき比 
と比較的よい対応関係を示した。

終りに当たり，本研究を遂行する上で有益な御助言を頂 いた，当時金沢大学工学部 米谷 茂教授に感謝申し上げま す. また，試料を提供して頂くとともに，本研究の実施に 際していろいろと御討論頂いたスカイアルミニウム(侏) 岡田健三氏拉よび関係各位の皆様に, 深く感謝申し上げま す.

\section{文献}

（1）中山栄浩, 鷹谷徹也: 軽金属, $40(1990), 599$.

（2）今井克哉, 米谷 茂: 軽金属, $40(1990), 109$.

（3）平修二, 吉岡靖夫：日本機械学会論文集, $30(1964), 1142$.

（4）平 修二, 吉岡靖夫 : 材料, 12(1963), 852 .

(5) 平 修二, 吉岡靖夫 : 材料試験, 11(1962), 675 .

（6）三好良夫：材料, 37(1988), 571 .

（7）例光ば, 谷 通弘, 英 崇夫, 藤原晴夫 : $\mathrm{X}$ 線材料 強度に関するシンポジゥム講演論文集 (日本材料学 会), (1990), 19.

(8) I. C. Noyan: Metall. Trans., 14A(1983), 249.

( 9 ) H. Dölle: J. Appl. Cryst., 12(1979), 489.

(10) W. H. Hall: J. Inst. Met., 75(1950), 1127.
（11）有間淳一，細川智生，本田和男：材料，18(1969), 1060.

（12）カリティ：X 線回折要論，アグネ，(1972), 266.

(13) $\mathrm{X}$ 線材料強度学, 日本材料学会編, 養賢堂, (1977), 261.

(14) 長嶋晋一：集合組織，丸善，(1984), 259.

（15） X 線応力測定法, 日本材料学会編, 養賢堂, (1990), 148.

（16）米谷 茂：日本金属学会誌，54(1990), 336 .

(17) S. Taira, K. Hayashi and Z. Watase: J. Soc. Mater. Sci. Jpn., 17(1968), 1151.

（18）若林三記夫, 中山 守, 玉村謙太郎 : 精密機械, $50(1984), 1481$.

（19）上城太一：日本金属学会誌, 32(1968), 22.

(20) 若林三記夫, 中山 守, 玉村謙太郎：精密機械, 49(1983), 1202

（21）若林三記夫, 中山 守, 玉村謙太郎：精密機械, 50 (1984), 544 .

（22）例完ば，英 崇夫，藤原晴夫：材料， 30(1981)， 1095 .

（23）宮川英明，大山司朗，小田 明：材料， $30(1981)$, 222.

（24）米谷 茂 : 残留応力の発生と対策, 養賢堂, (1987), 191.

（25）米谷 茂, 今井克哉, 能登谷久公 : 日本金属学会誌, 54(1990), 1120.

（26）小林信雄, 山崎良夫, 稲数直次 : 日本金属学会誌, 52(1988), 989. 